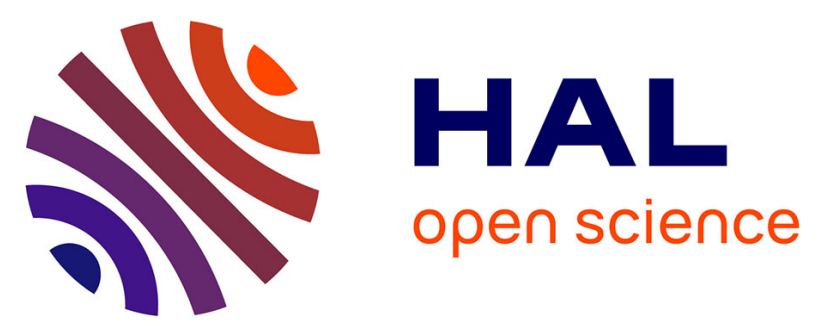

\title{
Measurement and Analysis of Malmquist Index of Health System Units in Fight against SARS-CoV-2 (COVID-19)
}

Nazila Adabavazeh, Mehrdad Nikbakht

\section{- To cite this version:}

Nazila Adabavazeh, Mehrdad Nikbakht. Measurement and Analysis of Malmquist Index of Health System Units in Fight against SARS-CoV-2 (COVID-19). 7th International Conference on Industrial and Systems Engineering (ICISE 2021), Sep 2021, Mashhad, Iran. 10.2139/ssrn.3961994. hal03426679

\section{HAL Id: hal-03426679 \\ https://hal.science/hal-03426679}

Submitted on 12 Nov 2021

HAL is a multi-disciplinary open access archive for the deposit and dissemination of scientific research documents, whether they are published or not. The documents may come from teaching and research institutions in France or abroad, or from public or private research centers.
L'archive ouverte pluridisciplinaire HAL, est destinée au dépôt et à la diffusion de documents scientifiques de niveau recherche, publiés ou non, émanant des établissements d'enseignement et de recherche français ou étrangers, des laboratoires publics ou privés. 


\title{
Measurement and Analysis of Malmquist Index of Health System Units in Fight againstSARS-CoV-2 (COVID-19)
}

\author{
Nazila Adabavazeh, Mehrdad Nikbakht" \\ Department of Industrial Engineering, Najafabad Branch, Islamic Azad University, Najafabad, Iran \\ *Corresponding author: Mehrdad Nikbakht Email:nikbakht2020@yahoo.com
}

\begin{abstract}
Today, health care is at a high level of dynamism. To survive in such conditions, performance assessment can play an effective role in providing quality health care. To develop and compete, health system units need a productivity assessment system to measure their programs and processes' efficiency and effectiveness. The purpose of this study is to measure the productivity changes of health system units using the Malmquist index. Productivity assessment of health system units provides the necessary information for managers to monitor these centers' current situation and activities. The present study's statistical population includes 28 units of the world health system with a minimum of 42 days of exposure to COVID-19. In this study, the performance of health system units has been measured based on 4 indicesthat include "Day of Infection, Total Cases" as inputs and "Total Deaths, Total Recovered" as outputsthat are from the "Worldometer" database.The present descriptive study was conducted in three 14-day COVID-19 incubation periods after the countries were exposed. The results showed that the mean of the productivity changes of the health system units did not have a steady growth trend so that the average changes of the total productivity of the health system units from the first to second incubation period was 0.92 and from the second to third incubation period was 1.58, which is an indication of the unstable growth in the productivity of the studied health system units.
\end{abstract}

Keywords:Data envelopment analysis, Malmquist Index, Health System Unit, Coronavirus.

\section{Introduction}

The existence of a performance assessment system is so vitalthat the lack of an assessment system in various dimensions, including the assessment of the use of the resources and capabilities, goals, and strategies, is considered as one of the symptoms of the disease of a health system unit(Sajadi HS et al., 2008). The quality of health care is the degree of services provided to communities that increases the likelihood of desirable outcomes and is consistent with present-day professional knowledge.

Assessing the productivity of health care systems is inevitable. This is vital when limited resources are encountered. Hospitals are of great importance as the largest and costliest units of operationin the health care system, so having a comprehensive method of productivity assessment to improve their status is of particular importance(Purbey, Mukherjee, \& Bhar, 2007).Lack of evaluation leads to increased costs in the treatment of the patients and neglect in providing health care services seriously endangers community health (Vali Pour-Khatir, 2014).

The most important service organizations in any community are health care providers that provide medical services to the general public using resources and facilities (Kittelsen et al., 2009). The rapid progress of human society in medical science causes an expanding need for various health services. Meanwhile, the health sector's financial resources are relatively

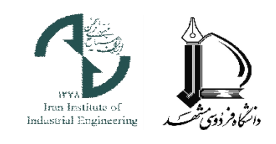


declining(Najafi et al., 2011). The economic limitations of resourcesarethe most important reason for paying more attention to productivity in all areas of corporate management.

Today, productivity and efficiency are considered a culture and vision in all human work and life environments and are the source of economic progress and development (REZAEI et al. 2008). Therefore, in the health sector,this category should be studied and analyzed.Calculating the efficiency and recognizing the effective factors in increasing the efficiency of health system units is a complementary measure intheir quantitative and qualitative development.Here are some of the studies that have been conducted on the productivity of health system units:

- Adabavazeh et al. (2020)assessed the performance of the world health system units based on the statistics of "population, days of exposure, number of the recovered patients, number of deaths, Gross Domestic Product (GDP), and number of patients" of the patients with coronavirus usingparametric and non-parametric statistical test techniques. Based on the obtained results, efficient and inefficient health system units were identified. The findings indicated that the majority of the countries under study did not operate efficiently due to their inability in the optimal use of resources.Inefficient health system units require more WHO attention in promoting the health culture in the management of common and prevalent virus crises.

- Alinezhad \& Mirmozaffari (2018)assessed the hospitals using input-oriented and outputorientedMalmquist Productivity Index (MPI). MPI is calculated to measure the productivity growth relative to a reference technology. The data coveredsix years from 2011 to 2016 for 15 local heart hospitals. Two inputs, one intermediate element, and two outputs were selected in a two-stage model, and these factors are the indicatorsof the hospitals' main performance. The conversion of a two-stage model to a single-stage model was introduced. This model was proposed to fix the efficiency of a two-step process and prevent dependence on various weights.Finally, the results showed that MPI's geometric mean in the input-oriented net pure technical efficiency (PTE) in the tenth hospital was introduced as the highest hospital performance with the highest rate of productivity growth.

- Javaheri (2014)assessed the productivity of the Iranian insurance industry based on the non-parametric Malmquist approach. This study examined the changes in total factor productivity (TFP) for all insurance companies in Iran from 2003 to 2009. Based on this method, the output-oriented Malmquist index was calculated.To determine the factors affecting the productivity growth of insurance companies, the regression model was used. The results of this study confirm the positive effect of liberalization policy in this industry on productivity growth. The results also indicate that the scale and type of insurance activity directly affect productivity growth.

- Mehrolhassani et al. (2019)assessed the educational section of medical universities' productivity in Iran using the data envelopment analysis method and the Malmquist index. The study assessed the performance of the educational section of 43 Iranian Medical Sciences Universities in three time periods using the data envelopment analysis method with an output-oriented approach.The results showed that medical schools have a favorable situation in the educational section in terms of efficiency. Productivity in this section also showed positive and increasing growth.To more accurately judge the educational performance of medical sciences universities, the use of qualitative measures in addition to quantitative measures seems essential.

- Dargahi and Toloui Rakhshan (2020) assessed Tehran University of Medical Sciences hospitals based on the Pabon Lasso model. General and performance indicators of

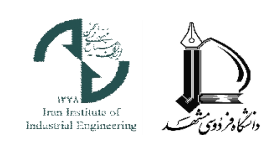


hospitals were used to access the data.The results showed that bed occupancy and average bed turnover indicators were increasing from the beginning to the end of five years and the average patients' hospitalization time was decreasing. Also, at the end of the five-year period, the studied hospitals were located in zone III of the Pabon Lasso diagram, which showed these hospitals' desirable performance during this period.

- Khodabakhshi et al. (2017) assessed the efficiency of Tehran University of Medical Sciences hospitals using data envelopment analysis.Input indicators were the number of active beds and the number of physicians (general, resident, and specialist) and output indicators were the total number of hospitalization days, the number of outpatients, and the total number of bed-day.

- Alinezhad and Khalili (2018)assessedhospitals' performance using the combined method of BSC and VFB-DEA in a fuzzy environment.In this regard, by studying the indicators used to assess the performance of health care centers in previous studies and with the opinions of health experts, three indicators of staff satisfaction and per capita training and cost of medicine and consumables, and three indicators of patient satisfaction and the average length of hospital stay and bed occupancy percentage, were selected as input and output indicators in four balanced scorecard perspectives. Then, using the new VFB-DEA model, efficient and inefficient units were determined.Regarding the considered uncertainty and the determination of the input and output indicators based on the balanced scorecard, the proposed model is more accurate than the previous models and enables managers to make better and more accurate decisions to improve the organizations' efficiency.

- Bastani et al. (2016) analyzed the performance of teaching hospitals of the Shiraz University of Medical Sciences using the Pabon Lasso model. Data were collected using the hospital's monthly activity form and the AVAB website (hospital statistics and information) and were analyzed by drawing the Pabon Lasso diagram and using the paired t-test.In general, the performance indicators of hospitals affiliated to Shiraz University of Medical Sciences were not in good condition compared to the standards.After the implementation of the health system reform plan, changes occurred in the statusof the hospitals. Therefore, it seems necessary for managers and policymakers in the health sector to improve efficiency and increaseresource utilization.

- Bahadori et al. (2017) assessed and ranked the performance of the wards of a military hospital using the data envelopment analysis model and PROMETHEE method.Based on the results obtained, out of 21 wards studied, 6 wards had an efficiency of more than 0.9 , and eventually, the ranking of the efficient wards of the military hospital was performed using the PROMETHEE method.

- In a study, Mehrolhasani and Barfeh (1970)assessed the performance of teaching hospitals of the Kerman University of Medical Sciences and the Social Security Organisation hospitals using the balanced scorecard (BSC).The study population was hospitals affiliated to Kerman University of Medical Sciences and Kerman Social Security Organization hospitals, where three medical teaching and Social Security Organisation hospitals were selected in a targeted trend.The central tendencies of frequency and percentage value were used to analyze the data. The results showed that Social Security Organisation hospitals performed better than medical teaching hospitals in the processing and customer satisfaction dimensions, and teaching hospitals had a better status in the financial and human resources dimensions. This study also showed that a balanced scorecard is a suitable tool for evaluating the performance of hospitals.

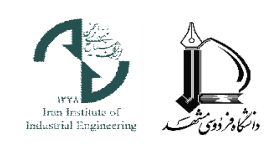


- (Raiisian et al., 2017)compared the productivity of academic and non-academic hospitals of Ahvaz's city using the Malmquist index and data envelopment analysis.Inputs for calculating productivity included the number of physicians, nurses, other staff, active beds, and outputs included the bed occupancy percentage, number of patients, and surgeries. The results showed that the overall productivity in university hospitals was better than in other hospitals.

The ever-increasing advances in medical knowledge and technology, and methods of health care and treatment on the one hand, and changing lifestyles and cultural and social structures, changing the pattern of diseases and medical needs of the people, and rapid population growth, on the other hand, have created new problems and obstacles against providing health care facilities and services. Besides, the optimal use of the material and human resources for the effective production and supply of health services requires knowledge of economic regulations(Andes, 2002).Improving economic efficiency allows a health system toperform better using the available resources and causejustice and equity toimprove (Lee et al.,2015). Given the ever-increasing circumstances of the process of globalization of the economy and the need to promote the competitiveness of health system units, analysis of the role of productivity and the relative effectiveness of the elements of each of them is necessary. Due to the importance of the issue, it is necessary to conduct a comprehensive study in this field to scrutinize the issue with more attention and more accurate analysis.

In this regard, using the data envelopment analysis method and Malmquist index, this study was conducted to estimate and assess the changes in total productivity and its determining elements in the health system units of 28 countries using data from the Worldometer database.

\subsection{Analysis of Malmquist Index}

In economic analysis, one of the indices that have always been considered in the study of productivity growth of all factors is the Malmquist productivity index.This index was first introduced by Malmquist ${ }^{1}$ as a standard index and was first used byCaves et al. (1982) in production theory.Caves et al. (1982)used the distance function to calculate the indices and assumed that all units were efficient concerning the production frontier of their time, $\mathrm{D}^{\mathrm{k}}\left(\mathrm{x}^{\mathrm{k}}, \mathrm{y}^{\mathrm{k}}\right)=1$. To calculate the productivity growth of a decision-making unit (DMU) during the time $t_{1}$ and $t_{2}$, they calculated the ratio of the distance function of the observations of that DMU at the abovementioned times concerning efficiency frontiers of the time $t_{1}, t_{2}$ and presented two productivity indices. The distance function is defined as the relation (1): $\mathrm{D}^{\mathrm{t} 2}\left(\mathrm{x}^{\mathrm{t} 1}, \mathrm{y}^{\mathrm{t} 1}\right)=\operatorname{Min}\left\{\theta \mid\right.$ when $\theta \mathrm{x}^{\mathrm{t} 1}$ can produce $\mathrm{y}^{\mathrm{t} 1}$ with the technology of time $\left.\mathrm{t}^{2}\right\}$

Due to the Farrell's definition of technical efficiency and the above-defined distance functionbeing identical, Färe et al. (1994). used data envelopment analysis techniques to calculate the Malmquist index and presented it in the geometric form mean of Malmquist productivity indices presented by Caves et al. (1982).

${ }^{1}$ Malmquist

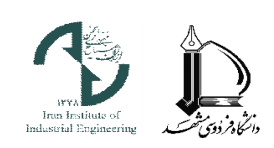




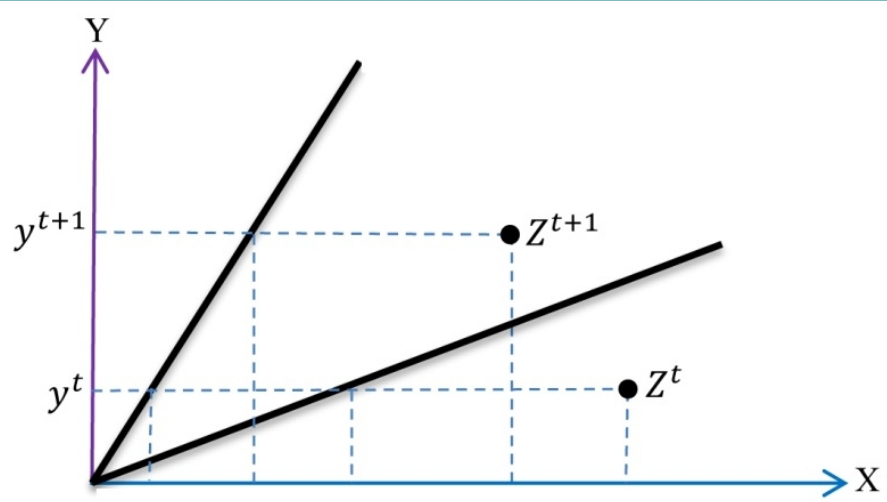

Figure 1. Malmquist productivity index

It is assumed that the number of decision-making units is $\mathrm{n}, . \mathrm{x}^{\mathrm{t1}}{ }_{\mathrm{j}}=\left(\mathrm{x}^{\mathrm{t} 1}{ }_{1 \mathrm{j}}, \ldots, \mathrm{x}^{\mathrm{t} 1}{ }_{\mathrm{mj}}\right)$ and $\mathrm{y}^{\mathrm{t} 1} \mathrm{j}=\left(\mathrm{y}^{\mathrm{t1}}{ }_{1 \mathrm{j}}, \ldots, \mathrm{y}^{\mathrm{t} 1}{ }_{\mathrm{sj}}\right)$ are the input and output vectors of the $\mathrm{j}^{\text {th }}$ decision-making unit, respectively. $(\mathrm{j} \in\{1, \ldots, \mathrm{n}\})$ at timet ${ }_{1}$, and $\mathrm{x}^{\mathrm{t} 2}{ }_{\mathrm{j}}=\left(\mathrm{x}^{\mathrm{t} 2}{ }_{1 \mathrm{j}}, \ldots, \mathrm{x}^{\mathrm{t} 2}{ }_{\mathrm{mj}}\right)$ and $\mathrm{y}^{\mathrm{t} 2}{ }_{\mathrm{j}}=\left(\mathrm{y}^{\mathrm{t} 2}{ }_{1 \mathrm{j}}, \ldots, \mathrm{y}^{\mathrm{t} 2}{ }_{\mathrm{sj}}\right)$ are respectively the input and output vectors of the abovementioned unit at time $t_{2}$. Based on the Malmquist productivity index, the productivity growth of the $\mathrm{o}^{\text {th }}$ decision-making unit (o $\in\{1, \ldots, n\})$ at time $t_{2}$ relative to $t_{1}$ is calculated from relation (4) Jahantighi (2012).

$$
\begin{aligned}
& T E_{o}=\frac{D_{o}^{t 2}\left(x_{o}^{t 2}, y_{o}^{t 2}\right)}{D_{o}^{t 1}\left(x_{o}^{t 1}, y_{o}^{t 1}\right)} \\
& T E C H_{o}=\left[\frac{D_{o}^{t 1}\left(x_{o}^{t 2}, y_{o}^{t 2}\right)}{D_{o}^{t 1}\left(x_{o}^{t 1}, y_{o}^{t 1}\right)} \times \frac{D_{o}^{t 2}\left(x_{o}^{t 2}, y_{o}^{t 2}\right)}{D_{o}^{t 2}\left(x_{o}^{t 1}, y_{o}^{t 1}\right)}\right]^{1 / 2} \\
& M P I_{o}=\frac{D_{o}^{t 2}\left(x_{o}^{t 2}, y_{o}^{t 2}\right)}{D_{o}^{t 1}\left(x_{o}^{t 1}, y_{o}^{t 1}\right)}\left[\frac{D_{o}^{t 1}\left(x_{o}^{t 2}, y_{o}^{t 2}\right)}{D_{o}^{t 2}\left(x_{o}^{t 2}, y_{o}^{t 2}\right)} \times \frac{D_{o}^{t 1}\left(x_{o}^{t 1}, y_{o}^{t 1}\right)}{D_{o}^{t 2}\left(x_{o}^{t 1}, y_{o}^{t 1}\right)}\right]^{1 / 2}
\end{aligned}
$$

If it is assumed that $D_{o}^{t 1}\left(x_{o}^{t 1}, y_{o}^{t 1}\right)$ and $D_{o}^{t 2}\left(x_{o}^{t 2}, y_{o}^{t 2}\right)$ should be equal 1 to be efficient, relative efficiency changes are calculated by Eq. (2). Fare states the rate of technological change between $\mathrm{t} 1$ and $\mathrm{t} 2 \mathrm{as}$ a geometric composition shown in Eq. (3). Malmquist productivity index is obtained by product of efficiency and technology changes according to Eq. (4).

Based on relative efficiency change, a piece of boundary that extends the production possibilitythat time $\mathrm{t} 2$ relative to the corresponding point at time $\mathrm{t} 1$ has had positive movement while the production possibility set be smaller, it has negative movement. The index of technological change is larger than 1 is a sign of progress;smaller than 1 is a sign of regression and equal to 1 is a sign of no change of boundaries.Malmquist Productivity Index is larger than 1 is a sign of increased productivity, smaller than 1 is a sign of declining productivity, and parity with 1 is a sign of no change in productivity.

The value of MPI is defined as a convex geometric composition that can determine the smallest weakness in the efficiency, and the slightest change in any efficiency affects the Malmquist productivity index (Jahantighi et al., 2012).

\section{Research Methodology}

The present study is a descriptive-analytical study that cross sectional examines the information of three time periods from March 1 to April 11. In the present study, the data envelopment analysis approach has been used to assess the three time periods' performance. The Malmquist index has been used to calculate productivity. The study population consists of 28 health system units of the Worldometer report with a minimum of 42 days of exposure to COVID-19 and non-zero data. Given that the world health system units seek to maximize their health care services, the basic output-oriented BCC model is proposed. Since secondary

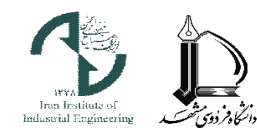


models can determine the amount of optimal improvement (reference set) of inefficient inputs and outputs, the output-oriented BCC envelopment model is used in this research. Fixed-scale efficiency is applicable if health system units operate at an optimal scale.However, various issues such as the constraints, medical capabilities, facilities, strategies of the countries, etc. cause the health care system units to not operate at an optimal scale. Analysis of the performance of health system units in the case of fixed-scale efficiency can be considered a long-term goal and in the case of the variable scale, efficiency can be considered a short-term goal for inefficient health system units. Research inputs include "Day of Infection, Total Cases" and the outputs include "Total Deaths, Total Recovered". The operational definition of research input and output is as follows:

- Total Deaths: It refers to the death rate of the country's population due to the coronavirus.

- Day of Infections: The number of days that the country has been officially exposed to the coronavirus.

- Total Cases: Number of patients who tested positive for coronavirus.

- Total Recovered: The number of patients with a negative retest after 14 days of exposure indicates that the virus has been completely eliminated from the infected person's body.

The required data were collected from the Worldometer database. After collecting the data and entering it in Excel software, the data were analyzed using DEA Frontier software, and the efficiency was calculated according to model (1). Evidence from the patients' analysis shows in about $80 \%$ of cases, this disease is mild (non-pneumonia or mild pneumonia) and leads to recovery (European Center for Disease Prevention and Control, 2020). On the other hand, the mortality rate is undesirable. With the introduction of these two rates,the mathematical model has been proposed in the form of model (1) (Adabavazeh et al., 2020). The efficiency of health system units is calculated and presented based on model (5).

$\operatorname{Max} \varphi$

St:

$$
\begin{array}{ll}
\varphi y_{r o}-\sum_{j=1}^{n} \lambda_{j}\left(\frac{1}{0.2 y_{1 j}}+0.8 y_{2 j}\right) \leq 0 & , r=1, \ldots, s \\
\sum_{j=1}^{n} \lambda_{j} x_{\mathrm{ij}} \leq x_{\mathrm{io}} & \\
\sum_{j=1}^{n} \lambda_{j}=1 & , i=1, \ldots, m \\
\lambda_{j} \geq 0, \forall_{j}, \varphi \text { free variable } &
\end{array}
$$

In this study, the inputs and outputs of health system units separately in 28 countries in three periods with a 14-day incubation period have been used. The trend of the changes and growth of total factor productivity (TFP) of the world health system units during the mentioned periods has been estimated using the Malmquist productivity index.

The Malmquist index measures the changes in the productivity of the units' total factors from period $t$ to period $t+1$ using the distance function. In the case of a change in the technological efficiency, it is determined that if a unit has the input value of period $t$, what change in the value of its efficiency will occur with the change of technology when it reaches period $t+1$, and/or if the input values of period $t+1$ are available, what change will the

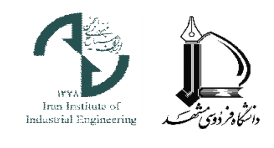


variation in technology make in the values of efficiency. It is worth mentioning that the calculation of productivity using the Malmquist index is studied over time and under dynamic conditions.Therefore, by having the information of three consecutive periods, the two Malmquist indices can be calculated for each health system unit. These indices include technical efficiency changes (TEC), technological changes (TECH), and total factor productivity changes (TFP).

Table 1. Data related to inputs and outputs of the research $(($ Worldometer, 2020), (WHO, 2020))

\begin{tabular}{|c|c|c|c|c|c|}
\hline \multicolumn{6}{|c|}{ 1-14 March } \\
\hline No. & Country & Day of Infection & Total Cases & Total Deaths & Total Recovered \\
\hline 1 & Algeria & 19 & 37 & 37 & 3 \\
\hline 2 & Australia & 50 & 248 & 248 & 3 \\
\hline 3 & Austria & 19 & 602 & 602 & 1 \\
\hline 4 & Azerbaijan & 16 & 15 & 15 & 1 \\
\hline 5 & Belgium & 40 & 689 & 689 & 4 \\
\hline 6 & Canada & 50 & 200 & 200 & 1 \\
\hline 7 & China & 64 & 80,824 & 80,824 & 3,189 \\
\hline 8 & Egypt & 30 & 93 & 93 & 2 \\
\hline 9 & France & 51 & 3,661 & 3,661 & 79 \\
\hline 10 & Germany & 48 & 3,758 & 3,758 & 8 \\
\hline 11 & Greece & 18 & 190 & 190 & 3 \\
\hline 12 & India & 45 & 84 & 84 & 2 \\
\hline 13 & Iran & 25 & 12,729 & 12,729 & 611 \\
\hline 14 & Iraq & 22 & 101 & 101 & 10 \\
\hline 15 & Italy & 45 & 17,660 & 17,660 & 1,266 \\
\hline 16 & Japan & 60 & 738 & 738 & 21 \\
\hline 17 & Lebanon & 23 & 93 & 93 & 3 \\
\hline 18 & Netherlands & 17 & 804 & 804 & 10 \\
\hline 19 & Norway & 18 & 1,032 & 1,032 & 1 \\
\hline 20 & Philippines & 45 & 98 & 98 & 8 \\
\hline 21 & S. Korea & 55 & 8,086 & 8,086 & 72 \\
\hline 22 & San Marino & 17 & 80 & 80 & 5 \\
\hline 23 & Spain & 44 & 5,753 & 5,753 & 136 \\
\hline 24 & Sweden & 44 & 821 & 821 & 2 \\
\hline 25 & Switzerland & 19 & 1,375 & 1,375 & 13 \\
\hline 26 & Thailand & 62 & 82 & 82 & 1 \\
\hline 27 & UK & 44 & 798 & 798 & 11 \\
\hline 28 & USA & 54 & 2,329 & 2,329 & 50 \\
\hline \multicolumn{6}{|c|}{ 15-28 March } \\
\hline No. & Country & $\begin{array}{c}\text { Day of } \\
\text { Infection }\end{array}$ & Total Cases & Total Deaths & Total Recovered \\
\hline 1 & Algeria & 33 & 409 & 409 & 26 \\
\hline 2 & Australia & 64 & 3,635 & 3,635 & 14 \\
\hline 3 & Austria & 33 & 7,712 & 7,712 & 68 \\
\hline 4 & Azerbaijan & 30 & 165 & 165 & 3 \\
\hline 5 & Belgium & 54 & 9,134 & 9,134 & 353 \\
\hline 6 & Canada & 64 & 4,757 & 4,757 & 55 \\
\hline
\end{tabular}


Table 1. Data related to inputs and outputs of the research ((Worldometer, 2020), (WHO, 2020))- Continued

\begin{tabular}{|c|c|c|c|c|c|}
\hline \multicolumn{6}{|c|}{ 15-28 March } \\
\hline No. & Country & $\begin{array}{c}\text { Day of } \\
\text { Infection }\end{array}$ & Total Cases & Total Deaths & Total Recovered \\
\hline 7 & China & 78 & 81,394 & 81,394 & 3,295 \\
\hline 8 & Egypt & 44 & 536 & 536 & 30 \\
\hline 9 & France & 65 & 32,964 & 32,964 & 1,995 \\
\hline 10 & Germany & 62 & 53,340 & 53,340 & 395 \\
\hline 11 & Greece & 32 & 966 & 966 & 28 \\
\hline 12 & India & 59 & 944 & 944 & 20 \\
\hline 13 & Iran & 39 & 35,408 & 35,408 & 2,517 \\
\hline 14 & Iraq & 36 & 458 & 458 & 40 \\
\hline 15 & Italy & 59 & 86,498 & 86,498 & 9,134 \\
\hline 16 & Japan & 74 & 1,499 & 1,499 & 49 \\
\hline 17 & Lebanon & 37 & 391 & 391 & 8 \\
\hline 18 & Netherlands & 31 & 8,603 & 8,603 & 546 \\
\hline 19 & Norway & 32 & 3,796 & 3,796 & 20 \\
\hline 20 & Philippines & 59 & 1,075 & 1,075 & 68 \\
\hline 21 & S. Korea & 69 & 9,478 & 9,478 & 144 \\
\hline 22 & San Marino & 31 & 223 & 223 & 21 \\
\hline 23 & Spain & 58 & 65,719 & 65,719 & 5,138 \\
\hline 24 & Sweden & 58 & 3,069 & 3,069 & 105 \\
\hline 25 & Switzerland & 33 & 13,187 & 13,187 & 240 \\
\hline 26 & Thailand & 76 & 1,245 & 1,245 & 6 \\
\hline 27 & UK & 58 & 14,543 & 14,543 & 759 \\
\hline 28 & USA & 68 & 104,256 & 104,256 & 1,704 \\
\hline \multicolumn{6}{|c|}{29 March -11 April } \\
\hline No. & Country & $\begin{array}{c}\text { Day of } \\
\text { Infection }\end{array}$ & Total Cases & Total Deaths & Total Recovered \\
\hline 1 & Algeria & 47 & 1,761 & 256 & 405 \\
\hline 2 & Australia & 78 & 6,292 & 56 & 3,265 \\
\hline 3 & Austria & 47 & 13,767 & 337 & 6,604 \\
\hline 4 & Azerbaijan & 44 & 991 & 10 & 159 \\
\hline 5 & Belgium & 68 & 28,018 & 3,346 & 5,986 \\
\hline 6 & Canada & 78 & 22,148 & 569 & 6,013 \\
\hline 7 & China & 92 & 81,953 & 3,339 & 77,525 \\
\hline 8 & Egypt & 58 & 1,304 & 135 & 384 \\
\hline 9 & France & 79 & 124,869 & 13,197 & 24,932 \\
\hline 10 & Germany & 76 & 122,530 & 2,736 & 53,913 \\
\hline 11 & Greece & 46 & 2,011 & 92 & 269 \\
\hline 12 & India & 73 & 7,876 & 249 & 774 \\
\hline 13 & Iran & 53 & 70,029 & 4,357 & 41,947 \\
\hline 14 & Iraq & 50 & 1,279 & 70 & 550 \\
\hline 15 & Italy & 73 & 147,577 & 18,849 & 30,455 \\
\hline 16 & Japan & 88 & 6,005 & 99 & 762 \\
\hline 17 & Lebanon & 51 & 619 & 20 & 76 \\
\hline 18 & Netherlands & 45 & 24,413 & 2,643 & 250 \\
\hline
\end{tabular}


Table 1. Data related to inputs and outputs of the research ((Worldometer, 2020), (WHO, 2020))- Continued

\begin{tabular}{|c|c|c|c|c|c|}
\hline \multicolumn{7}{|c|}{ No. } & Country & $\begin{array}{c}\text { Day of } \\
\text { Infection }\end{array}$ & Total Cases & Total Deaths & Total Recovered \\
\hline 19 & Norway & 46 & 6,360 & 114 & 32 \\
\hline 20 & Philippines & 73 & 4,428 & 247 & 157 \\
\hline 21 & S .Korea & 83 & 10,480 & 211 & 7,243 \\
\hline 22 & SanMarino & 45 & 344 & 34 & 50 \\
\hline 23 & Spain & 72 & 161,852 & 16,353 & 59,109 \\
\hline 24 & Sweden & 72 & 10,151 & 887 & 381 \\
\hline 25 & Switzerland & 47 & 24,900 & 1,003 & 11,100 \\
\hline 26 & Thailand & 90 & 2,518 & 35 & 1,135 \\
\hline 27 & UK & 72 & 73,758 & 8,958 & 344 \\
\hline 28 & USA & 82 & 503,177 & 18,761 & 27,314 \\
\hline
\end{tabular}

\section{Results}

Considering the inputs and outputs of the research model, the three time periods' efficiency was calculated according to Table (1). Then the Malmquist index was analyzed according to Tables (2 and 3). The Malmquist value measures relative changes over a period of time. The MPI index of health system units greater than 1 will be considered a positive change value and the MPI index of health system units less than 1 will be considered a negative value.

Table 2. Changes in the productivity index from the first incubation period (March 1-14) to the second incubation period (March 15-28)

\begin{tabular}{|c|c|c|c|}
\hline Health System Unit & TFP & TECH & $\mathrm{TE}$ \\
\hline Algeria & 0.150425 & 0.597458 & 0.251774 \\
\hline Australia & 0.219125 & 0.337626 & 0.649018 \\
\hline Austria & 0.041521 & 0.867287 & 0.047875 \\
\hline Azerbaijan & 0.729713 & 0.729713 & 1 \\
\hline Belgium & 0.313363 & 0.611055 & 0.512823 \\
\hline Canada & 0.087484 & 1.050888 & 0.083248 \\
\hline China & 1 & 1 & 1 \\
\hline Egypt & 0.420461 & 0.648044 & 0.648815 \\
\hline France & 9.055347 & 0.617486 & 14.66485 \\
\hline Germany & 0.665079 & 0.61608 & 1.079534 \\
\hline Greece & 0.147351 & 0.45558 & 0.323437 \\
\hline India & 0.183144 & 0.606077 & 0.302179 \\
\hline Iran & 0.89598 & 0.453864 & 1.974117 \\
\hline Iraq & 0.66059 & 0.509561 & 1.296389 \\
\hline Italy & 2.243923 & 0.932889 & 2.405347 \\
\hline Japan & 1.45554 & 0.975669 & 1.491839 \\
\hline Lebanon & 0.613297 & 0.544739 & 1.125856 \\
\hline Netherlands & 0.01019 & 0.184193 & 0.05532 \\
\hline Norway & 0.086704 & 0.577779 & 0.150063 \\
\hline Philippines & 0.310435 & 0.870535 & 0.356602 \\
\hline S. Korea & 2.397354 & 0.467512 & 5.127898 \\
\hline San Marino & 0.18461 & 0.258386 & 0.714476 \\
\hline Spain & 1.839622 & 0.954322 & 1.927674 \\
\hline Sweden & 0.023705 & 0.411852 & 0.057558 \\
\hline Switzerland & 0.777996 & 0.183959 & 4.229174 \\
\hline Thailand & 0.290275 & 0.579167 & 0.501193 \\
\hline UK & 0.070018 & 0.627951 & 0.111502 \\
\hline USA & 1.122388 & 0.575239 & 1.951168 \\
\hline
\end{tabular}


In moving from the first to the second incubation period, the efficiency of the health system units of "France, Germany, Iran, Iraq, Italy, Japan, Lebanon, Netherlands, S. Korea, Spain, Switzerland, USA" has increased.The efficiency of the health system units of "Azerbaijan, China" has not changed, and other health system units' efficiency has decreased.

The technology change index shows that progress is observed in the health system units of "Canada". In other words, this period's transition has had a positive frontier and the collection has expanded the possibility of production.In the "China" health system unit, the frontier does not change.Other countries' health system units have had a negative regression or negative frontiershift, and the collection of their production capacity has shrunk and moved inward.

The MPI of the health system units of "France, Italy, Japan, S. Korea, USA" indicates increased productivity or progress. The MPI of the health system units of "China" shows that there has been no change in productivity for the first and second incubation periods (time $t$ and $t+1$ ). The MPIs of other health system units' productivity decreasedand a regression is observed in these countries.

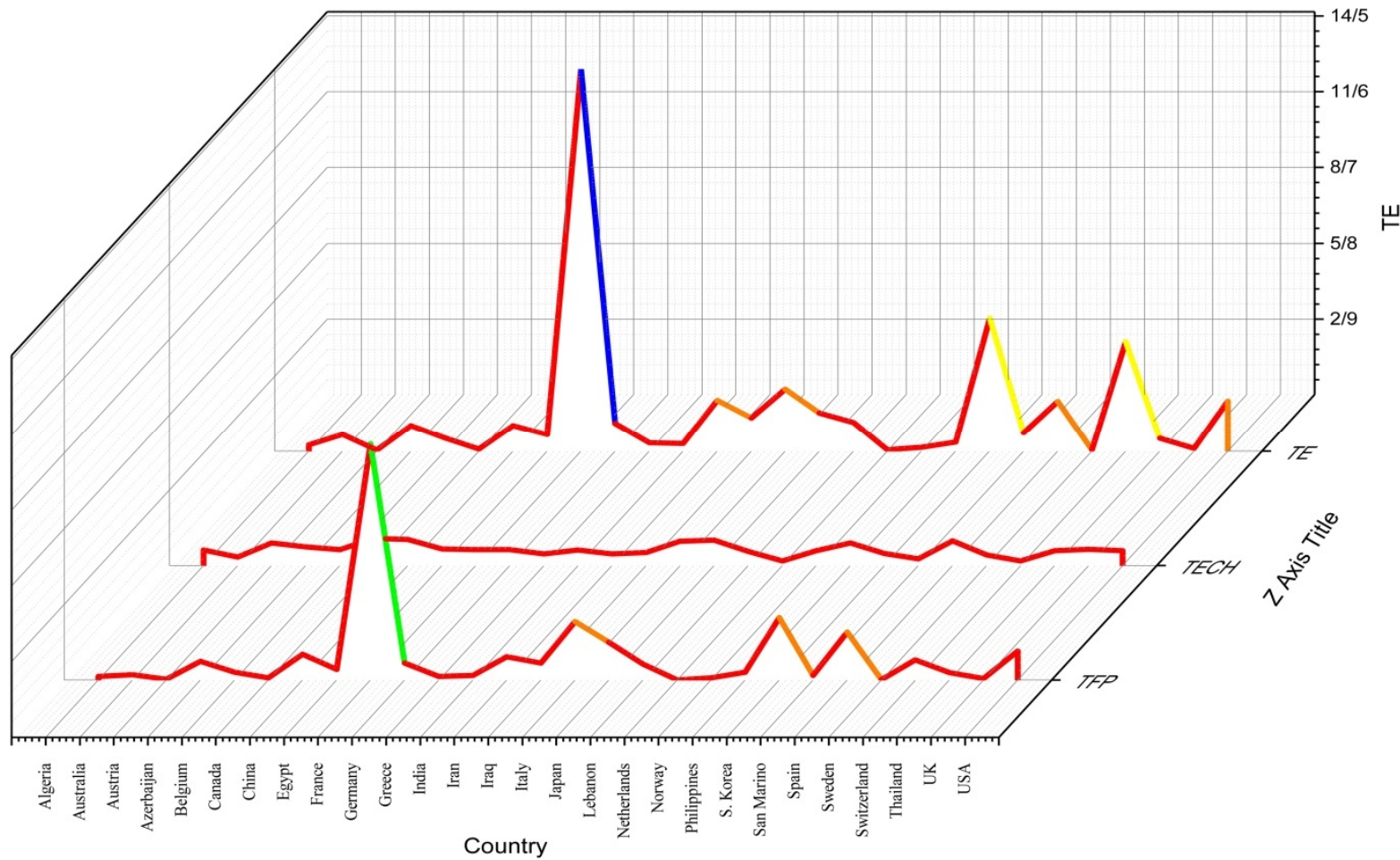

Figure 2. Diagram of changes using the Malmquist index during the first and second incubation periods

Forthe transition from the second incubation period to the third incubation period, the productivity index changeshave been presented in Table (2) and the diagram of the change is shown in Figure (3). The trend of the changes and growth of the total factor productivity (TFP) of the world health system units during the transition from the second incubation period to the third incubation period has been estimated using the Malmquist productivity index.

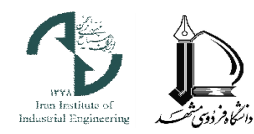


Table 3 - Changes in the productivity index from the second incubation period (March 15-28) to the third incubation period (March 29-April 11)

\begin{tabular}{|c|c|c|c|}
\hline Health System Unit & TFP & TECH & TE \\
\hline Algeria & 0.808942 & 0.336518 & 2.403859 \\
\hline Australia & 1.463677 & 0.550341 & 2.65958 \\
\hline Austria & 2.853507 & 0.184167 & 15.49412 \\
\hline Azerbaijan & 0.870075 & 0.870075 & 1 \\
\hline Belgium & 1.805715 & 1.017984 & 1.773815 \\
\hline Canada & 2.354481 & 0.676367 & 3.481069 \\
\hline China & 1 & 1 & 1 \\
\hline Egypt & 0.665759 & 0.541055 & 1.230483 \\
\hline France & 1.910539 & 0.947198 & 2.017044 \\
\hline Germany & 5.358836 & 0.847762 & 6.321155 \\
\hline Greece & 0.523192 & 0.299197 & 1.748652 \\
\hline India & 0.203791 & 0.283532 & 0.718758 \\
\hline Iran & 1.09757 & 0.911104 & 1.20466 \\
\hline Iraq & 0.850621 & 0.619947 & 1.372087 \\
\hline Italy & 2.025754 & 0.967777 & 2.093203 \\
\hline Japan & 0.428118 & 0.861205 & 0.497115 \\
\hline Lebanon & 0.626686 & 0.279469 & 2.242416 \\
\hline Netherlands & 0.324114 & 0.034449 & 9.408425 \\
\hline Norway & 0.125182 & 0.213586 & 0.586095 \\
\hline Philippines & 0.522433 & 0.516979 & 1.01055 \\
\hline S. Korea & 1.358474 & 1.01383 & 1.339943 \\
\hline San Marino & 1.393499 & 0.199143 & 6.99748 \\
\hline Spain & 4.421196 & 0.948545 & 4.66103 \\
\hline Sweden & 0.783442 & 0.553177 & 1.41626 \\
\hline Switzerland & 1.084522 & 0.448118 & 2.420171 \\
\hline Thailand & 0.77345 & 0.671208 & 1.152325 \\
\hline UK & 0.471994 & 0.746406 & 0.632355 \\
\hline USA & 8.36593 & 0.891258 & 9.386655 \\
\hline & & &
\end{tabular}

During the transition from the second incubation period to the third incubation period, the efficiencies of the health system units of "India, Japan, Norway, UK" have decreased. The efficiencies of the health system units of "Azerbaijan, China" have not changed and the efficiencies of other health system units have increased.

The technology change index shows that progress has been made in the health system units of "Belgium, S. Korea", in other words, they have had a positive frontier shift. In the Health System Units of "China", the frontier has not changed. Other health system units have had a regression or negative frontier shift. The assessment of the total factor productivity (TFP) of health system units in "Australia, Austria, Belgium, Canada, France, Germany, Iran, Italy, S. Korea, San Marino, Spain, Switzerland, USA" indicates increased productivity and shows progress. The TFP of health system units in "China" shows that there have been no changes in productivity for the second and third incubation periods. The TFP of other health system units shows a decrease in productivity and regression is observed in these countries.

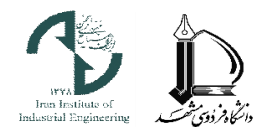




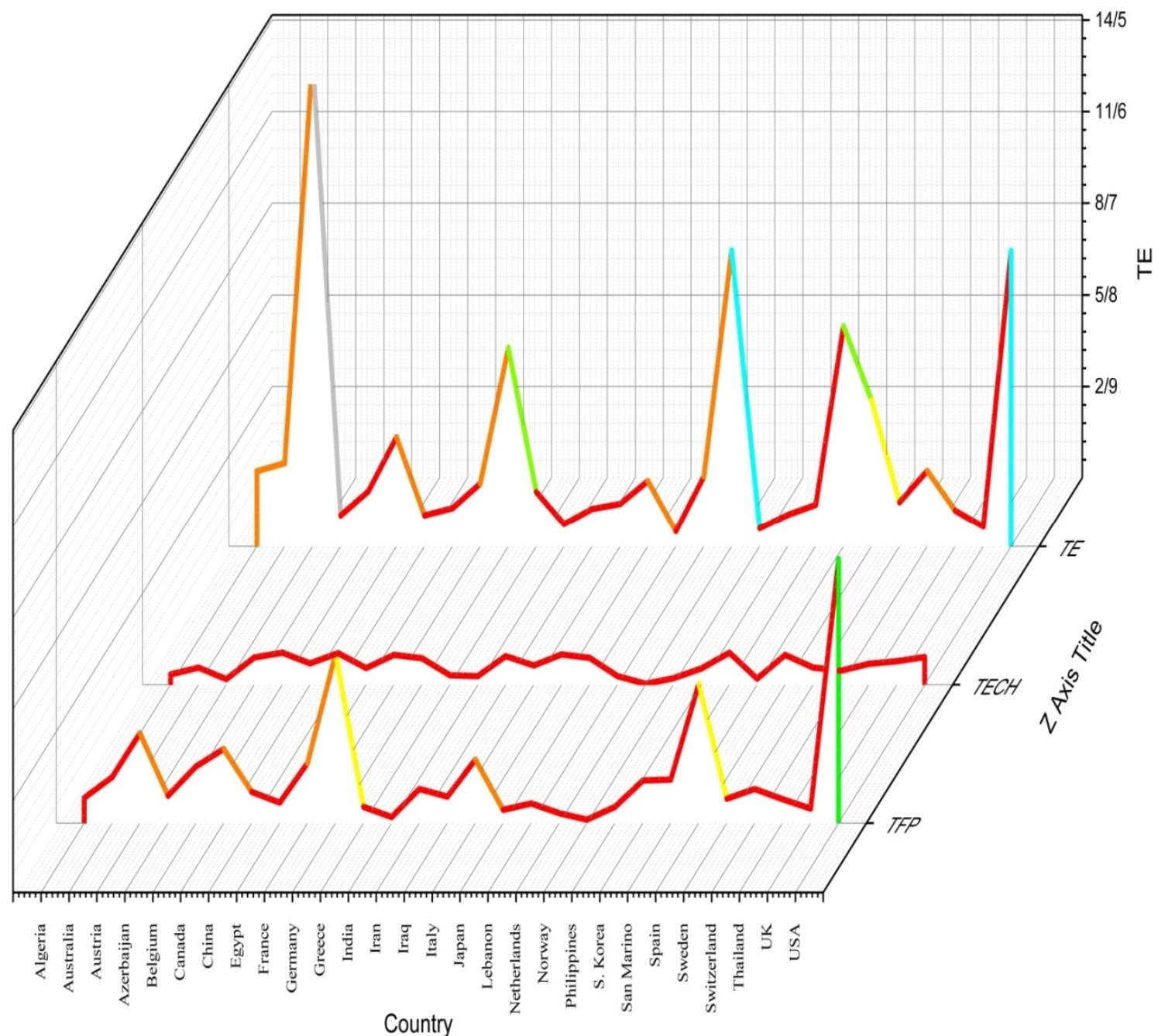

Figure 3.Diagram of changes using the Malmquist index during the second and third incubation periods

\section{Discussion and Conclusion}

Malmquist Productivity Index is a good criterion for determining the changes and growth of productivity in a system.By distinguishing the causes of productivity changes, this productivity index helps the managers of economic enterprises provide solutions to improve productivity. In a case mining,the health system units of 28 countries with a minimum of 42 days of exposure have been assessed. Based on the results of the implementation of the model, it can be said that in cases where efficiency changes and technology changes are more significantthan 1, the productivity index is greater than 1 and this has led to positive productivity growth, and if both become less than 1, the productivity index will also become less than 1 and the productivity will have negative growth. The examination of the total factor productivity changes shows that the second incubation period had the highest productivity growth and the third incubation period had less productivity. The average productivity changes of health system units did not have a stable growing trend so that the average productivity changes of all health system units from the first to second incubation period was 0.92 and from the second to the third incubation period was 1.58 , which this fact indicates an unstable growth in the productivity of the studied health system units.

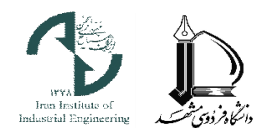


The productivity of health system units has witnessed a productivity loss from the first to the second incubation period and progress in productivity from the second to the third incubation period.

These results provide the WHO with a clear and specific perspective of the world health system units' capacity so that the WHO can make appropriate decisions to strengthen the weaknesses and improve the shortcomings bases on these results and present these decisions to the world health system units.Also, the world health system units can assess each of the studied cases' success ratewith regard to the defined policies of that unit.

The patterns of the factors affecting productivity increase in different units are similar to each other; however, the composition and priority of factors affecting productivity are different due to the internal and external environments' characteristics.Factors such as management, customer orientation, human resource improvement, hospital technology and equipment, organizational culture, job satisfaction, and employee motivation effectively improve productivity. Improving productivity and quality is the result of a conscious process, and the productivity growth can only be achieved with paying proper attention to the management factor, promoting the culture of productivity at work, improving the quality of work-life in hospitals, organizing pieces of training and improving human resources, and employing appropriate hospital equipment.

Strengthening the performance of health system units, health security, and increasing the participation should be enacted, implemented, and developed by the WHO in the form of international laws such that factors such as wealth, discrimination, and inequality cannot pose a threat especially to inefficient and poor unitsduring the crises.

Despite the progress in various medical sciences in the treatment and control of infectious diseases, without doubt, the introduction and description of the background of common infectious diseases considerably help to understand the epidemiological situation of the diseases.In this regard, the development of a protocol by an international observer body such as WHO is recommended.The development of protocols in times of crisis can improve health care in health system centers.

The most important problems of the health system units whenfacing crises are the weakness in thecrisis committee's activities, lack of a system for organizing medical staff, failure to hold training courses, failure to use new technologies, andshortage of human resources and medical equipment.Proper crisis management will be possible by developing plans for crisis management, making necessary coordination measures inside and outside the organization during the crises, especially with the use of novel technologies, identifying and the existing capabilities to deal with the crises by strengthening the workforces and their proper organization, and providing the necessary training.Proper planning on how to use the resources, training, prevention, and the culture of the promotion of the prevention of the spread of the virus will play a significantrole in reducing the costs and resources of the health system units.

\section{References}

Purbey, S., Mukherjee, K., \& Bhar, C. (2007). Performance measurement system for healthcare processes. International Journal of Productivity and Performance Management, 56, 241-251. doi: 10.1108/17410400710731446.

Sajadi HS, Hariri MH, Karimi S, Baratpour S. (2008). Performance Self Assessment by the Excellence Model in Different Hospitals of Isfahan University of Medical Sciences and Healthcare Services 2006. Research in Medicine. 32 (3) :227-231, URL: http://pejouhesh.sbmu.ac.ir/article-1-522-en.html.

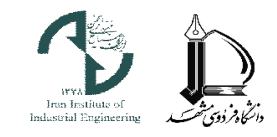


Vali Pour-Khatir, M., Narjes Qasem-Nia. (2014). Introducing a model for the assessment of the efficiency of hospitals in realizing the vision of the reform of the health care system. Paper presented at the International Conference on Management in the 21st Century, Tehran.

Kittelsen, Sverre \& Magnussen, Jon \& Anthun, Kjartan Sarheim \& Unto, Linna, Miika \& Medin, Emma \& Olsen, Kim \& Rehnberg, Clas. (2009). Hospital productivity and the Norwegian ownership reform - A Nordic comparative study. Oslo University, Health Economics Research Programme, HERO On line Working Paper Series.

Najafi B, Behesti Dehkordi A, Emami Meibodi A. The productivity of general hospitals of Ardebil Province (1999-2006). Journal of Inflammatory Diseases. 2011; 14 (4) : 64-70, URL: http://journal.qums.ac.ir/article-1-1037-en.htm

Rezaei, j., Soltani, h. a., Tavakoli baghdadabad, m. r., \& hosseini, m. a. (2008). evaluation of total factor productivity changes in iranian commercial banks lising malmquist index, Iranian Journal of Trade Studies, 12(48), 69-101.

Adabavazeh, N., Nikbakht, M., \& Amirteimoori, A. (2020). Envelopment analysis for global response to novel 2019 Coronavirus-SARS-COV-2 (COVID-19). Journal of Industrial Engineering and Management Studies, 7(2), 1-35. doi: 10.22116/jiems.2020.226564.1354

Alireza Alinezhad, Mirpouya Mirmozaffari. Malmquist Productivity Index Using Two-Stage DEA Model in Heart Hospitals. Iranian Journal of Optimization, Islamic Azad University Rasht Branch, 2018, 10 (2), pp.81-92.

Sadraei Javaheri, A. (2014). Productivity Evaluation of Iranian Insurance Industry: A Non-Parametric Malmquist Approach. Iranian Journal of Economic Research, 18(57), 85-95.

Mehrolhassani M, Goudarzi R, Yazdi Feyzabadi V, Pourhosseini S, Darvishi A. Efficiency and Productivity Measurement in Research Sector of Iranian Medical Sciences Universities Using Data Envelopment Analysis and Malmquist Index. irje. 2019; 14 :1-11 URL: http://irje.tums.ac.ir/article-1-6139-en.html

Dargahi, H., Toloui Rakhshan, S. (2017). Performance Assessment of Hospitals Affiliated to Tehran University of Medical Sciences Using the Pabon Lasso Model: a fiveyear trend study. Health and Development Journal, 6(3), 206-215.

Khodabakhshi M, Dargahi H, Moammai H. Efficiency Assessment and Ranking of TUMS Hospitals Using Data Envelopment Analysis. payavard. 2017; 11 (4) :460-468 URL: http://payavard.tums.ac.ir/article-1-6359-en.html

Alinezhad, A., Khalili, J. (2018). Performance Evaluation Model for Hospitals Using BSC and Fuzzy VFB-DEA. , 7(2). http://jdep.iaukhsh.ac.ir/article_536821_en.html

Bastani P, Lotfi F, Moradi M, Ahmadzadeh M. The Performance Analysis of Teaching Hospitals Affiliated with Shiraz University of Medical Sciences Before and After Health System Reform Plan Using Pabon Lasso Model. JRUMS. 2016; 15 (8) :781-792 URL: http://journal.rums.ac.ir/article-1-3165-en.html

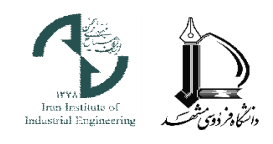


Bahadori, M. k., Abolghasemi, K., \& Teymourzadeh, E. (2017). Performance evaluation and ranking of selective wards in a military hospital using DEA and promethee method. Journal of Military Medicine Winter 2017 ,Volume 18, Issue 4,325-334

Mehrolhasani, M., Barfeh, T. (1970). Performance Assessment for Teaching Hospitals Affiliated to Kerman University of Medical Sciences and Kerman social security Hospitals by Using the Balanced Scorecard. Journal of Sabzevar University of Medical Sciences, 22(2), 461-471.

Andes S, Metzger LM, Kralewski J, Gans D. Measuring efficiency of physician practices using data envelopment analysis. Managed Care (Langhorne, Pa.). 2002 Nov;11(11):48-54. PMID: 12491859.

Lee, Keon-Hyung PhD, MPH; Park, Jungwon PhD; Lim, Seunghoo PhD; Park, SangChul PhD Has Competition Increased Hospital Technical Efficiency?, The Health Care Manager: April/June 2015 - Volume 34 - Issue 2 - p 106-112.

doi: 10.1097/HCM.0000000000000061

JAHANTIGHI, M., MOGHADDAS, Z., \& VAEZ, G. (2012). MULTI STAGES MALMQUIST PRODUCTIVITY INDEX. Journal of Operational Research and Its Applications. 2012; 4 (31), 59-70.

Caves, D., Christensen, L., \& Diewert, W. (1982). The Economic Theory of Index Numbers and the Measurement of Input, Output, and Productivity. Econometrica, 50(6), 1393-1414. doi:10.2307/1913388.

Färe R., Grosskopf S., Lindgren B., Roos P. (1994) Productivity Developments in Swedish Hospitals: A Malmquist Output Index Approach. In: Data Envelopment Analysis: Theory, Methodology, and Applications. Springer, Dordrecht. https://doi.org/10.1007/97894-011-0637-5_13.

Bastani P, Lotfi F, Moradi M, Ahmadzadeh M. The Performance Analysis of Teaching Hospitals Affiliated with Shiraz University of Medical Sciences Before and After Health System Reform Plan Using Pabon Lasso Model. JRUMS. 2016; 15 (8) :781-792 URL: http://journal.rums.ac.ir/article-1-3165-en.html

WHO. (2020) Retrieved [accessed on 11/04/2020], from https://www.who.int

Worldometer. (2020a) Retrieved [accessed on 14/03/2020 12:10 GMT], from https://www.worldometers.info/coronavirus

Worldometer. (2020b) Retrieved [accessed on 28/03/2020], from https://www.worldometers.info/coronavirus

Worldometer. (2020c) Retrieved [accessed on 11/04/2020 12:56 GMT], from https://www.worldometers.info/coronavirus

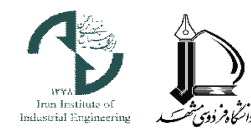

